\title{
Far-Eastern grey voles (Rodentia: Cricetidae: Alexandromys) from Bolshoi Shantar Island
}

\author{
Nikolai E. Dokuchaev
}

\begin{abstract}
Ognev (1929) assigned grey voles from Bolshoi Shantar Island to the root vole, separating them in a subspecies Microtus (= Alexandromys) oeconomus shantaricus Ognev, 1929. However, the shape of first lower molar anterior cup does not allow attributing of these specimens to root vole. Among FarEastern grey voles inhabiting the neighboring mainland, Gromov's vole (Alexandromys gromovi Vorontsov et al., 1988) is listed. The attribution of the voles from Shantar Island to the latter species is confirmed by the similarity in fur coloration, exterior, occlusal surface pattern of $\mathrm{m} 1$, and geographic proximity. The final conclusion could be made after the molecular analysis of the Far-Eastern grey voles from Bolshoi Shantar Island and mainland. In the event of their identity according to the priority rule, both should get the name Alexandromys shantaricus (Ognev, 1929), and A. gromovi should be considered as a junior synonym of the latter.
\end{abstract}

KEY WORDS: Alexandromys oeconomus shantaricus, Alexandromys gromovi, Bolshoi Shantar Island, Far-Eastern grey voles.

Nikolai E. Dokuchaev [dokuchaev@ibpn.ru], Institute of Biological Problems of the North FEB RAS, Portovaya str., 18, Magadan 685000, Russia.

\section{Дальневосточные серые полевки (Rodentia: Cricetidae: Alexandromys) острова Большой Шантар}

\section{Н.Е. Докучаев}

РЕЗЮМЕ. Серых полевок с острова Большой Шантар Огнев (1929) отнес к полевке-экономке, выделив их в отдельный подвид Microtus (= Alexandromys) oeconomus shantaricus Ognev, 1929. Изучение зубов, однако, показало, что по форме передней непарной петли первого нижнего коренного зуба эти полевки не могут быть полевками-экономками. Среди дальневосточных серых полевок, населяющих сопредельные с Шантарскими островами материковые территории, числится полевка Громова (Alexandromys gromovi Vorontsov, Boeskorov, Lyapunova et Revin, 1988). Из-за сходства в окраске меха, экстерьере и рисунке жевательной поверхности $\mathrm{m} 1$, и с учетом географического распространения, делается предположение об идентичности этих таксонов. Окончательный вывод можно будет сделать после молекулярного анализа форм дальневосточных серых полевок острова и материковой части. В случае их идентичности, согласно правилу приоритета, они должны будут получить название Alexandromys shantaricus (Ognev, 1929), с переходом названия $A$. gromovi в младшие синонимы.

КЛЮЧЕВЫЕ СЛОВА: о-в Большой Шантар, дальневосточные серые полевки, Alexandromys oeconomus shantaricus, Alexandromys gromovi.

\section{Introduction}

Shantar Islands is an archipelago of 15 big and small islands which are located in the west "corner" of the Sea of Okhotsk between E $136^{\circ} 29^{\prime}$ and $138^{\circ} 25^{\prime}$, and $\mathrm{N} 54^{\circ} 20^{\prime}$ and $55^{\circ} 10^{\prime}$ in the entrance to the Tugursk Bay. All islands are of continental origin, separated from the mainland 9.5-10 thousand years ago (Velizhanin, 1976). Bolshoi Shantar Island is the largest among them (Fig. 1).

Because of the relatively recent separation of Bolshoi Shantar Island from the mainland, the rodent species that inhabit it do not differ from the mainland's ones. At least two red-backed voles - Myodes rutilus (Pallas, 1779) and Craseomys rufocanus (Sundevall, 1846), as well as Siberian flying squirrel Pteromys volans (L., 1758), red squirrel Sciurus vulgaris L., 1758, and Siberian chipmunk Tamias sibiricus (Laxmann, 1769) belong to the same subspecies as on the mainland (Kostenko, 2000). Grey voles from Bolshoi Shantar were identified as root vole (Ognev, 1929). However, this species identification should be checked. In the voles' diagnosis Ognev noted that they are characterized by rich reddish-brown fur color, shortened tail, wide skull, and a more complicated structure of the first lower molar. Based on these characters Ognev separated these 


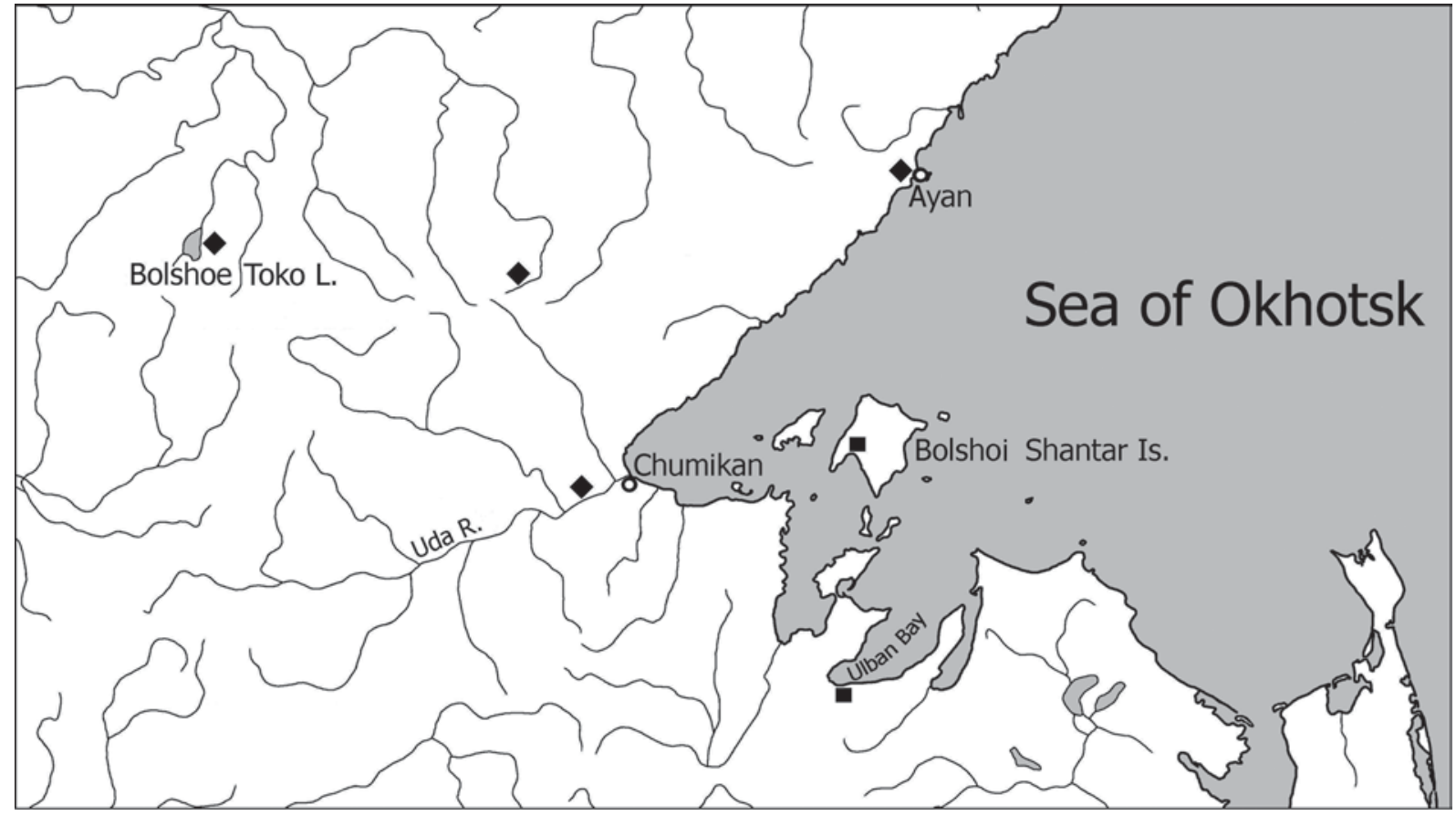

Figure 1. Map of species findings: Alexandromys oeconomus shantaricus (squares), and Alexandromys gromovi (diamonds); (by Ognev, 1929; Vorontsov et al., 1988; Bannikova et al., 2010; Lissovsky et al., 2010; Sheremetyeva et al., 2010).

voles in a new subspecies Microtus (= Alexandromys) oeconomus shantaricus Ognev, 1929. Ognev (1950) extended the range of this new subspecies to the entire coast of Sea of Okhotsk from Ulban Bay in the South (Fig. 1) up to Penzhina River basin in the North.

Zoologists from the Institute of Biology and Soil Science, Far Eastern Branch of Russian Academy of Sciences (Vladivostok, Russia) in 1973 and 1977 years collected the series of Far-Eastern grey voles in Bolshoi Shantar Island. They did versatile comparison of these voles and root voles from other territories of the Far East (Kostenko \& Allenova, 1983, 1989). Considering the obvious differences Kostenko (2000) supposed that A. oeconomus shantaricus can constitute a separate species, but he did not make a final conclusion. Thus, this form until recently remained in status of subspecies of root vole (Gromov \& Polyakov, 1977; Pavlinov \& Rossolimo, 1987; Gromov \& Erbajeva, 1995; Kostenko, 2000; Musser \& Carleton, 2005; Abramson \& Lissovsky, 2012).

Gromov's vole was originally identified as one of subspecies of $A$. maximowiczi (Vorontsov et al., 1988). Morphological, karyological, and genetic studies that were later conducted allowed to consider the "gromovi" form as an independent species (Sheremetyeva et al., 2003, 2009; Frisman et al., 2009; Bannikova et al., 2010; Lissovsky et al., 2010; Haring et al., 2011).

During the description of subspecies A. maximowiczi gromovi it was already noted that there are differences in morphotypes of first lower molar $\mathrm{m} 1$ between right and left jaws (Vorontsov et al., 1988). Detailed study of m1 in Gromov's voles (Voyta et al., 2013) also had shown that some individuals have "oeconomuslike" fusion between anterior cap (AC) and T5. This fusion clearly differentiates Gromov's voles, root vole, and Mongolian vole $A$. mongolicus (Radde, 1861) from other species (Voyta et al., 2013).

\section{Material and methods}

Only five specimens of $A$. oeconomus shantaricus were available for study (Fig. 3a-e). Three specimens of $A$. oeconomus shantaricus (including holotype) deposited in the Zoological Museum of Moscow State University (ZMMU, Moscow, Russia), and two in the Zoological Institute of the Russian Academy of Sciences (ZIN, Saint Petersburg, Russia). The variation of $\mathrm{m} 1$ morphotypes in several Alexandromys species from Siberia and Far-Eastern Russia was studied based on the specimens from ZMMU, ZIN and IBPN (Institute of Biological Problems of the North, Far Eastern Branch of the Russian Academy of Sciences, Magadan, Russia) collections, including Far-Eastern grey voles from Bolshoi Shantar Island and Gromov's vole (for specimens ID see Appendix). Due to the limited material from Shantar Islands my research based mainly on the AC shape of the first lower molar $\mathrm{m} 1$. The peculiarities in fur coloration, exterior (tail length), and two measurements ("a" and "b"; see Fig. 2) of m1 (separately for the right and left $\mathrm{m} 1$ ) were also taken into account. 


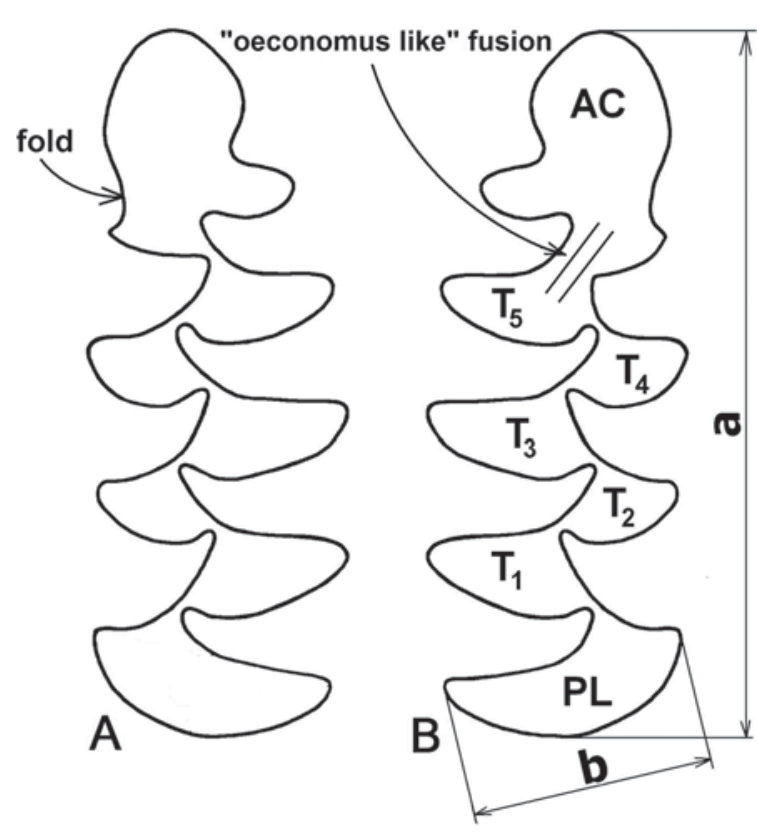

Figure 2. The elements of first lower molar $\mathrm{ml}$ occlusal pattern of Gromov's vole: AC — anterior cap; PL — posterior lobe; $\mathrm{T}_{1-5}$ - triangles of the occlusal surface. Measurements: $\mathrm{a}-\mathrm{m} 1$ length; $\mathrm{b}-$ posterior lobe width. $\mathrm{A}-\mathrm{m} 1$ with seven enamel-dentine closed loops on occlusal surface; $\mathrm{B}-\mathrm{m} 1$ with six enamel-dentine closed loops on occlusal surface, and "oeconomus-like" fusion.

\section{Results}

The first lower molar of the holotype specimen of $A$. oeconomus shantaricus (ZMMU S-31137) showed seven separate enamel-dentine islets and four buccal salient angles (BSA). There is a slight asymmetry in the expression of the buccal fold of the AC. In the right jaw, it is less prominent than in the left one (Fig. 3a).

Specimen ZMMU S-127218 showed the similar to the type specimen occlusal surface morphology (Fig. 3b). The ZMMU S-31138 demonstrated simple AC, and "oeconomus-like" fusion between $\mathrm{AC}$ and $\mathrm{T} 5$ for both sides (Fig. 3c). Two specimens from ZIN collection (ZIN 69487 and ZIN 69488) have asymmetric AC and different expressions of "oeconomus-like" fusion of this (Fig. 3d, e). The Gromov's vole occlusal surfaces of $\mathrm{m} 1$ showed on Figure 3 ( $\mathrm{f}, \mathrm{g}$ ). The specimen ZMMU S-187549 has six separate enamel-dentine islets, while ZMMU S-187550 has seven ones. Other studied specimens had different transitional variants. Thereby, among Far-Eastern grey vole specimens from Bolshoi Shantar Island and Gromov's vole demonstrated most unstable elements on $\mathrm{m} 1$ then another species of mainland. This result according to previously morphological studies (Vorontsov et al., 1988; Voyta et al., 2013).

\section{Discussion}

The most specimens of root vole are known to have six enamel-dentine islets and three BSA of m1 (Gromov \& Erbajeva, 1995). Sometimes the simple buccal side of AC formed convexity without buccal fold, whereby the fourth angle does not appear (Kovaleva et al., 2002; Kropacheva et al., 2012). Specimens ZMMU S31137 and ZMMU S-127218 from Bolshoi Shantar Island showed seven enamel-dentine islets and four BSA of $\mathrm{m} 1$. The rest ones demonstrated six enameldentine islets (except left $\mathrm{m} 1$ of ZIN 69487), "oeconomus-like" fusion between AC and T5, and buccal fold of AC. Therefore none of five specimens of Far-Eastern gray voles from Bolshoi Shantar Island can belong to root vole by the $\mathrm{m} 1$ occlusal surface patterns.

Average $\mathrm{m} 1$ length of grey voles from Bolshoi Shantar Island was $2.9 \pm 0.09 \mathrm{~mm}$, and posterior lobe width was $1.2 \pm 0.05 \mathrm{~mm}(n=10)$. In root vole from northern part of Sea of Okhotsk coast the same measurements were as $2.8 \pm 0.01 \mathrm{~mm}$, and $1.1 \pm 0.01 \mathrm{~mm}(n=60)$ correspondingly. The Gromov's vole they were $2.6 \pm 0.15$ $\mathrm{mm}$, and $1.0 \pm 0.07 \mathrm{~mm}(n=14)$. Thereby voles from Bolshoi Shantar Island are larger than $A$. oeconomus and $A$. gromovi from the mainland. Perhaps we have here so-called "island effect", when the individuals in islands are larger than in the mainland.

Kostenko and Allenova (1989) treated Far-Eastern grey voles from Bolshoi Shantar Island as root vole. They conducted a comparative morphological analysis of root vole throughout Far East of Russia and showed that specimens from Bolshoi Shantar Island had shorter tails (Kostenko \& Allenova, 1989). Voles from Bolshoi Shantar Island have tail length ranged from $25-41 \mathrm{~mm}$ (average $33.2 \mathrm{~mm} ; n=9$ ). According to Sheremetyeva with co-authors $(2003,2009)$ the tail length of adult individuals of the Gromov's voles was 34-36 mm (average $35 \mathrm{~mm} ; n=7)$. Type specimen of Gromov's vole from Bolshoe Toko Lake (young specimen) has tail length only $22.6 \mathrm{~mm}$. Thus, the tail length the FarEastern grey voles from Bolshoi Shantar Island and Gromov's vole are pretty close, and differ to another Alexandromys species, which inhabiting along the continental coast of the Okhotsk Sea (Krivosheev, 1984).

One of the distinguishing characteristics of FarEastern grey voles from Bolshoi Shantar Island is their rich reddish-brown color of fur on the back (Ognev, 1929; Kostenko \& Allenova, 1983, 1989). The Gromov's vole coloration also noted: the back is of dark grey-brown color dominated ochre-brown tones (Sheremetyeva et al., 2003, 2009). So both forms resemble in fur color.

During the last sea-level regression, Bolshoi Shantar Island was fused with the mainland. The adjacent mainland territories currently inhabited by the following species of Far-Eastern grey voles: A. oeconomus (Pallas, 1776), A. fortis (Buchner, 1889), A. maximowiczii (Schrenck, 1859), and A. gromovi (Vorontsovet al., 1988) (Dokuchaev, 2012). Considering to the geo- 

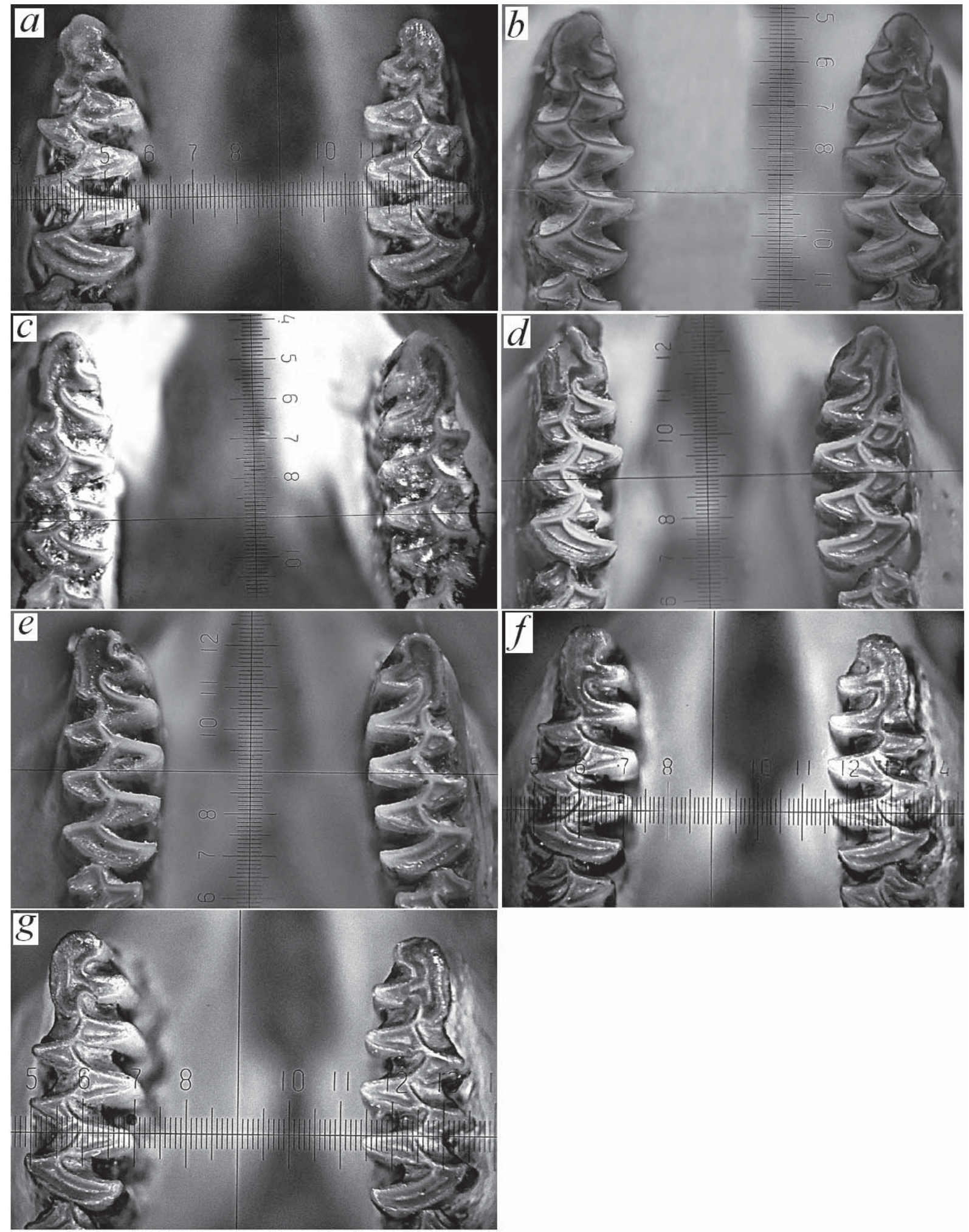

Figure 3. The first lower molars of Alexandromys voles from Bolshoi Shantar Island: a - S-31137 (holotype of $A$. $o$. shantaricus, ZMMU), b - S-127218 (ZMMU), c - S-31138 (ZMMU), d - 69487 (ZIN), e — 69488 (ZIN); and Gromov's vole: $\mathrm{f}$ - S-187549 (ZMMU), g — S-187550 (ZMMU). 
graphical location, peculiarities in fur coloration, exterior (tail length), and the $\mathrm{m} 1$ occlusal surfaces patterns the form "A. oeconomus shantaricus" and Gromov's vole maybe represent as the island and mainland populations of the same species. The final conclusion could be made after the molecular analysis of the Far-Eastern grey voles from Bolshoi Shantar Island. In the event of their identity according to the priority rule, both should get the name Alexandromys shantaricus (Ognev, 1929), and $A$. gromovi should be considered as a junior synonym of the latter.

ACKNOWLEDGMENTS. I would like to thank three anonymous reviewers for their helpful comments and useful recommendations regarding a previous version of the manuscript. The study was supported in part by Russian Federation Basic Research grant No. 12-0400018-a.

\section{References}

Abramson N.I. \& Lissovsky A.A. 2012. Subfamily Arvicolinae Gray 1821 // Pavlinov I.Ya. \& Lissovsky A.A. (eds). The Mammals of Russia: A Taxonomic and Geographic Reference. (Archives of Zoological Museum of MSU. Vol. 52). Moscow: KMK Scientific Press. P.220-276.

Bannikova A.A., Lebedev V.S., Lissovsky A.A., Matrosova V., Abramson N.I., V. Obolenskaya E.V. \& Tesakov A.S. 2010. Molecular phylogeny and evolution of the Asian lineage of vole genus Microtus (Rodentia: Arvicolinae) inferred from mitochondrial cytochrome $b$ sequence // Biological Journal of the Linnean Society. Vol.99. P.595-613.

Dokuchaev N.E. 2012. [Shrews (Soricomorpha) and rodents (Rodentia) distribution peculiarities on the Sea of Okhotsk continental coast] // Vestnik Severo-Vostochnogo Nauchnogo Tsentra Dalnevostochnogo Otdeleniya Rossiiskoi Akademii Nauk. No.3. P.118-123 [in Russian].

Frisman L.V., Korobitsyna K.V., Kartavtseva I.V., Sheremetyeva I.N. \& Voyta L.L. 2009. Voles (Microtus Shrank, 1798) of the Russian Far East: allozymic and karyological divergence // Russian Journal of Genetics. Vol.45. No.6. P.707-714.

Gromov I.M. \& Erbajeva M.A. 1995. [The Mammals of Russia and Adjacent Territories. Lagomorphs and Rodents]. Sankt-Peterburg: Izdatel'stvo Zoologicheskogo Instituta. 520 p. [in Russian].

Gromov I.M. \& Polyakov I.Ya. 1977. [Fauna of the USSR. Voles (Microtinae): Mammals]. Leningrad: Izdatel'stvo Nauka. Vol.3. No. 8. 504 p. [in Russian]

Haring E., Sheremetyeva I.N. \& Kryukov A.P. 2011. Phylogeny of Palearctic vole species (genus Microtus, Rodentia) based on mitochondrial sequences // Mammalian Biology. Vol.76. P.258-267.

Kostenko V.A. \& Allenova T.V. 1989. [Intraspecies differentiation of the root vole in the Far East and distributional history of its subspecific forms] // Kostenko V.A. (ed.). Teriologicheskie issledovaniya na yuge Dal'nego Vostoka. Vladivostok: Izdatel'stvo Dal'nevostochnogo Otdeleniya Akademii Nauk SSSR. P.4-25 [in Russian].
Kostenko V.A. \& Allenova T.V. 1983. [On the taxonomic status of root vole from Bolshoi Shantar Island (Sea of Okhotsk)] // Gromov I.M. (ed.). [Rodents: Proceedings of the VI All-Union Conference (Leningrad, 25-28 January 1984)]. Leningrad: Izdatel'stvo Nauka. P.85-86 [in Russian].

Kostenko V.A. 2000. [Rodents (Rodentia) of the Far East of Russia]. Vladivostok: Izdatel'stvo Dalnauka. 210 p. [in Russian]

Kovaleva V.Yu., Pozdnyakov A.A. \& Efimov V.M. 2002. [Investigation of variability structure of root vole $(\mathrm{Mi}$ crotus oeconomus Pallas) molar morphotypes using bilateral asymmetry] // Zoologicheskii Zhurnal. Vol.81. No.1. P.111-117 [in Russian].

Krivosheev V.G. (ed.). 1984. [Terrestrial Mammals of the USSR Far East. Key]. Moskva: Izdatel'stvo Nauka. 359 p. [in Russian]

Kropacheva Yu.E., Smirnov N.G. \& Markova E.A. 2012. [Individual age and odontologic characteristics of root vole] // Doklady Akademii Nauk USSR. Vol.446. No.2. P.234-237 [in Russian].

Lissovsky A.A., Obolenskaya E.V., Abramson N.I., Dokuchaev N.E., Yakimenko V.V., Mal'kova M.G., Bogdanov A.S. \& Ivanova N.V. 2010. Geographic variation of Microtus middendorffii (Cricetidae, Arvicolinae, Rodentia) sensu lato studied by craniometrical and mitochondrial features // Russian Journal of Theriology. Vol.9. No.2. P.71-81.

Musser G.G. \& Carleton M.D. 2005. Superfamily Muroidea // Wilson D.E. \& Reeder D.M. (eds.). Mammal Species of the World. A Taxonomic and Geographic Reference. Third edition. Baltimore: Johns Hopkins University Press. P.894-1531.

Ognev S.I. 1950. [The Mammals of the USSR and Adjacent Countries. Rodents]. Vol.7. Moskva-Leningrad: Izdatel'stvo AN SSSR. 706 p. [in Russian].

Ognev S.I. 1929. [The Mammals of the Shantar Islands] // Bulletins of the Pacific Scientific Fishery Research Station. Vol.2. No.5. P.1-44 [in Russian].

Pavlinov I.Ya. \& Rossolimo O.L. 1987. [Systematics of the USSR Mammals]. (Archives of Zoological Museum of MSU. Vol.25). Moskva: Izdatel'stvo MGU. 285 p. [in Russian]

Sheremetyeva I.N., Kartavtseva I.V., Voyta L.L., Kryukov A.P. \& Haring E. 2009. Morphometric analysis of intraspecific variation in Microtus maximowiczii (Rodentia, Cricetidae) in relation to chromosomal differentiation with reinstatement of Microtus gromovi Vorontsov, Boeskorov, Lyapunova et Revin, 1988, stat. nov. // Journal of Zoological Systematics and Evolutionary Research. Vol.47. No.1. P. 42-48.

Sheremetyeva I.N., Kartavtseva I.V., Voyta L.L. \& Tiunov M.P. 2010. [New data on distribution of voles of the genus Microtus (Rodentia, Cricetidae) from the Russian Far East] // Zoologicheskii Zhurnal. Vol.89. No.10. P. 1273-1276 [in Russian].

Sheremetyeva I.N., Kartavtseva I.V. \& Kryukov A.P. 2003. [The chromosomal and morphological characteristics of Microtus maximowiczii gromovi Vorontsov et al., 1988] // Averianov A.O. \& Abramson N.I. (eds.). [Systematics, Phylogeny and Paleontology of Small Mammals: Pro- 
ceedings of International Conference, devoted to the 90th anniversary of Prof. I.M. Gromov (November 24-27, 2003, Saint Petersburg)]. Sankt-Peterburg: Izdatel'stvo Zoologicheskogo Instituta. P. 236-238 [in Russian].

Velizhanin A.G. 1976. [The time of the islands' isolation in the north part of the Pacific Ocean] // Doklady Akademii Nauk SSSR. Vol.231. No.1. P. 205-207 [in Russian].

Vorontsov N.N., Boeskorov G.G., Lyapunova E.A. \& Revin Yu.V. 1988. [A new chromosome form and variability of molars in voles Microtus maximowiczii (Rodentia, Cricetidae)] // Zoologicheskii Zhurnal. Vol.67. No.2. P. 205214 [in Russian].

Voyta L.L., Golenishchev F.N. \& Tiunov M.P. 2013. Analysis of shape and size variation of the first lower molar in Far-Eastern grey voles of genus Alexandromys (Rodentia: Cricetidae) from Russian fauna using geometric morphometrics // Russian Journal of Theriology. Vol.12. No.1. P.19-32.

\section{APPENDIX}

The list of specimens used for measurements of $\mathrm{m} 1$. Information is in the following order: scientific name, geographical locality, geographical coordinates in parenthesis, housed place, sample size in parenthesis, specimen ID.

Alexandromys oeconomus shantaricus: Bolshoi Shantar Island, Khabarovsk Territory, Russia $\left(54^{\circ} 52^{\prime} \mathrm{N}\right.$, 137²9’E) — ZMMU ( $n=3)$ : S-31137, S-31138, S-127218; ZIN ( $n=2): 69487,69488$.

A. gromovi: Ayan, Khabarovsk Territory, Russia $\left(56^{\circ} 27^{\prime} \mathrm{N}, 138^{\circ} 09^{\prime} \mathrm{E}\right)-\mathrm{ZMMU}(n=1)$ : S-87335; Dzhana River, Khabarovsk Territory, Russia $\left(55^{\circ} 31^{\prime} \mathrm{N}, 134^{\circ} 05^{\prime} \mathrm{E}\right)$ - ZMMU $(n=1)$ : S-187569; Uchur River basin, Khabarovsk Territory, Russia $\left(55^{\circ} 46^{\prime} \mathrm{N}, 134^{\circ} 11^{\prime} \mathrm{E}\right)$ - ZMMU ( $\left.n=5\right)$ : S-187547, S-187549, S-187550, S-187565, S-187567.

A. oeconomus: Okhotsk environs, Khabarovsk Territory, Russia $\left(59^{\circ} 29^{\prime} \mathrm{N}, 143^{\circ} 18^{\prime} \mathrm{E}\right)-\operatorname{IBPN}(n=2)$ : 1064 , 1065; Magadan environs $\left(59^{\circ} 34^{\prime} \mathrm{N}, 150^{\circ} 49^{\prime} \mathrm{E}\right)$ - IBPN ( $\left.n=3\right)$ : 3835, 3836, 3837; Khasyn River, Magadan Province $\left(60^{\circ} 04^{\prime} \mathrm{N}, 150^{\circ} 44^{\prime} \mathrm{E}\right)$ - IBPN $(n=1)$ : 1067 ; Elikchan Lakes, Magadan Province $\left(60^{\circ} 45^{\prime} \mathrm{N}, 151^{\circ} 47^{\prime} \mathrm{E}\right)-$ IBPN $(n=25)$ : 1068, 1069, 1070, 1071,1072, 1073, 1074, 1075, 1076, 1077, 1078, 1079, 1080, 1081, 1082, 1083, $1084,1087,1088,1089,1091,1092,4358,4360,4361$. 